\title{
Macroinvertebrate biomass estimates in Cantabrian streams and relationship with brown trout (Salmo trutta) populations
}

\author{
Tamara Morante*, Loreto García-Arberas, Alvaro Antón and Ana Rallo \\ Department of Zoology and Animal Cell Biology. Faculty of Science and Technology. University of the Basque \\ Country. P.O. BOX 6444808 Bilbao. \\ * Corresponding author: morante.tamara@gmail.com
}

Received: 13/10/2011

Accepted: 7/11/2011

\begin{abstract}
Macroinvertebrate biomass estimates in Cantabrian streams and relationship with brown trout (Salmo trutta) populations

In this work, the average biomass of 80 relatively common families of benthic macroinvertebrates in the streams of the Biscay region (Basque Country, northern Iberian Peninsula) was estimated. The macroinvertebrates were collected using a kick net and preserved alive in cool aerated stream water. The fresh weight, dry weight, and ash-free dry weight (AFDW) were obtained for each family. The biomass values obtained were applied to more than a hundred macroinvertebrate samples collected from 1997 to 2006 in 17 stretches of 14 rivers inhabited by brown trout. The total and partial biomass of each sample was estimated. Significant differences in the density $(F=2.91 ; \mathrm{df}=16,100 ; P<0.001)$ and biomass $(F=6.52 ; \mathrm{df}=16,100$; $P<0.001$ ) of the macroinvertebrates occurred among the stations, with up to a 11 -fold and 17 -fold range, respectively. The brown trout population size was positively correlated to both the macroinvertebrate abundance and biomass. By age classes, this relationship was significant for only the $1+$ and $2+$ trout. The AFDW metric is recommended because it represents the real organic biomass value that joins the trophic food chain, avoiding an overestimation of the energy contribution of taxa with shells or cases. The Gammaridae had higher values of AFDW than expected, due to their high content of organic matter. A positive selection of gammarids by the trout was also observed in some cases.
\end{abstract}

Key words: Macroinvertebrates, benthic, dry weight, ash-free dry weight, trout, diet, Iberian Peninsula, Spain.

\section{RESUMEN}

Estimas de biomasa de macroinvertebrados en ríos cantábricos y su relación con las poblaciones de trucha común (Salmo trutta)

Se ha estimado la biomasa media de las 80 familias de macroinvertebrados bentónicos presentes habitualmente en ríos de Bizkaia (País Vasco, Norte de la Península Ibérica). Los macroinvertebrados se recogieron con red Kick y se conservaron vivos en agua del río con aireación forzada. Se obtuvo el peso fresco, el peso seco y el peso seco libre de cenizas (PSLC) para cada familia. Estos valores de biomasa se aplicaron a más de un centenar de muestras de macroinvertebrados recogidas entre 1997 y 2006 en 17 tramos de 14 ríos habitados por trucha común. Se estimó la biomasa total y parcial para cada muestra. Se observaron diferencias significativas entre las estaciones, de hasta 11 veces en términos de abundancia $(\mathrm{F}=2.91 ; d f=16$, 100; $\mathrm{P}<0.001)$ y de hasta 17 veces en la biomasa total $(\mathrm{F}=6.52 ; d f=16,100 ; \mathrm{P}<0.001)$ de macroinvertebrados. El tamaño de la población de truchas apareció correlacionado positivamente con la abundancia y biomasa total de macroinvertebrados. Diferenciando por clases de edad, estas relaciones fueron significativas sólo para las clases $1+$ y 2+. Se recomienda el uso del PSLC ya que éste representa la fracción de biomasa que realmente se incorpora a la cadena trófica, evitando sobrevalorar la aportación energética de los taxones con conchas o estuches. Los gammáridos mostraron valores de PSLC mayores de los esperados, lo que conlleva un elevado contenido en materia orgánica. En algunos casos, la trucha seleccionaba positivamente este grupo.

Palabras clave: Macroinvertebrados, bentónicos, peso seco, peso seco libre de cenizas, trucha, dieta, Península Ibérica, España. 


\section{INTRODUCTION}

Freshwater macroinvertebrates have wide ranges of sensitivities to changes in habitat quality and are frequently used in river-monitoring studies (Allan, 1995). Macroinvertebrates can be found in almost all environments, even in very contaminated zones. Most of them are quite sedentary, at least in their larval phases, and can therefore be used to detect pollution sources and to quantify habitat degradation (Hellawell, 1986; Hauer \& Resh, 1996).

Macroinvertebrates are also an essential link in aquatic food webs because they contribute to the transfer of matter and energy from the organic resources up to the top levels, as the principal food resource for other invertebrates and fishes (Rodrigues-Capítulo et al., 2009). Estimates of the mass of freshwater benthic organisms are often required for studies of invertebrate growth and production and of the feeding ecology of fish (Johnston \& Cunjak, 1999). There are several direct and indirect methods for assessing individual weights
(Crisp, 1984), some of them involving relationships between length and weight (Hauer \& Benke, 1987; Wenzel et al., 1990). However, a determination of fresh weight is not possible in many cases because macroinvertebrate samples are usually fixed or frozen after collection and consequently, biomass is frequently estimated from preserved organisms (Monzón et al., 1991; Basaguren et al., 1996; Bis et al., 2000; Ormerod et al., 2004).

The aim of the present study was to obtain the average mass (fresh, dry and ash-free dry weight) of the most frequent families of the macroinvertebrates inhabiting the rivers of Biscay (Cantabrian basin) and to develop a method that would permit the storage of macroinvertebrate samples without a loss of information about their biomass.

To assess the validity of this tool, we have applied the biomass values obtained in this study to several datasets of previous macroinvertebrate samples. Those datasets were collected previously by our research team for the evaluation of brown trout (Salmo trutta) populations during a long-term study in the river network of Biscay.

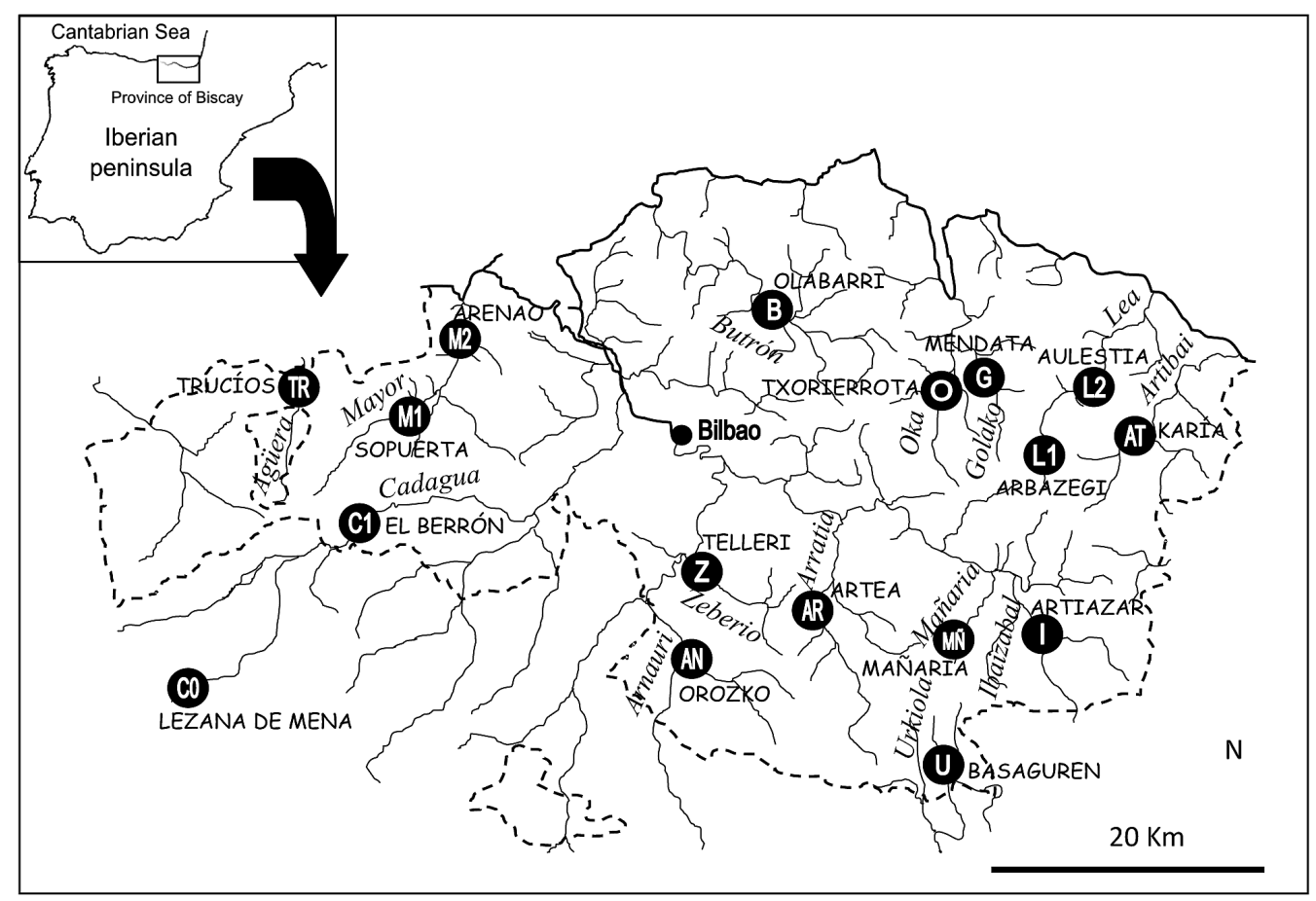

Figure 1. Fluvial network of Biscay, demonstrating the location of the sampling sites. Red fluvial de Bizkaia. Localización de las estaciones de muestreo. 


\section{METHODS}

The streams of the province of Biscay (Basque Country, northern Iberian Peninsula) (Fig. 1) are short, with relatively steep slopes, fluctuating flow rates and maximum levels in spring and autumn (Rallo, 1992). Macroinvertebrate samples were collected in March and April 2009 in four small streams of this river network: Mayor, Cadagua, Golako and Oka (all $2^{\text {nd }}$ order rivers except Cadagua, which is $3^{\text {rd }}$ order). Although the province of Biscay is a highly populated area (> 500 inhabitants $\left./ \mathrm{km}^{2}\right)$ with an important industrial tradition, the sampling reaches were in moderately to well-conserved areas, mainly dedicated to farming and forestry, with almost no industrial activity and low population density $\left(<50\right.$ inhabitants $\left./ \mathrm{km}^{2}\right)$.

The macroinvertebrates were collected using a kick net with a mesh size of $500 \mu \mathrm{m}$ following the standard method (Rico et al., 1992). To increase the number of collected families, some additional macroinvertebrates were captured by manual sampling. The organisms were preserved alive in cool stream water with an aeration system to modify them as little as possible while the measurements were completed.

The samples were separated using a binocular microscope and identified to the family level (Puig, 1999; Tachet et al., 2000). Several replica were made for each family. Three different weight values were obtained for each sample (SARTORIUS R $200 \mathrm{D}$ balance; $0.00001 \mathrm{~g}$ error): the fresh weight (FW), measured by blotting the animals on filter paper for 1 minute before weighing (Dermott \& Paterson, 1974; Leuven et al., 1985); dry weight (DW), measured after drying at $80^{\circ} \mathrm{C}$ for 24 hours to reach a constant weight; and ash weight, measured following incineration at $450{ }^{\circ} \mathrm{C}$ for 9 hours. The ash-free dry weight (AFDW) of each family was obtained by subtracting the ash weight from the dry weight (Brower \& Zar, 1979; Rodrigues-Capítulo et al., 2009). In the cases of great differences among the length of the individuals of a taxon, the individuals were grouped into two or three size classes, and the mean weight of each class was determined. The size classes were accepted when the coefficient of variation of the determined weight measurement (fresh, dry or ash-free dry) exceeded $60 \%$. Below this threshold, the weights were considered homogeneous (Sokal \& Rohlf, 1995; Jensey et al., 2000).

The mean weights of each family, obtained as explained above, were applied to the previously collected data of 145 samples of macroinvertebrates collected during a monitoring study, "Fish communities in the rivers of Biscay", funded by the Diputación Foral de Bizkaia/Bizkaiko Foru Aldundia (Rallo et al., 2001; 2007; Antón, 2006). Those samples were taken from 1997 to 2006 in 17 sampling stations of 13 rivers draining the Cantabrian basin (Agüera, Mayor, Cadagua, Arnauri, Zeberio, Arratia, Mañaria, Ibaizabal, Butrón, Oka, Golako, Lea and Artibai) and one river in the Ebro basin (Urkiola) (Fig. 1). The macroinvertebrates were sampled using the same kick net, and constant effort was employed in all of the cases, covering a surface of approximately $0.5 \mathrm{~m}^{2}$, allowing for a comparison among the sampling sites of the macroinvertebrate abundance. The families were classified into six different functional feeding groups (Merritt \& Cummins, 1978 and Tachet et al., 2000), and the total and partial biomass (categorised by the families and functional feeding groups) of each sample was calculated.

The fish data from the database of the Laboratory of Zoology of the University of the Basque Country (UPV/EHU) were also used. The fish collections were made using a catch removal method, assuming a constant capture per unit effort and making as many passes as necessary, between 2 and 5 , until a sufficient depletion of the captures was obtained (Lobón-Cerviá, 1991). The brown trout densities were calculated using the Pop/Pro modular statistical software (Kwak, 1992). The trout were individually measured (to the nearest $\mathrm{mm}$ ) and weighed (to the nearest $\mathrm{g}$ ). A scale sample was obtained from each animal for an age determination.

The relationship between the dry weight and ash-free dry weight values was analysed using a regression analysis. An analysis of variance was used to identify differences among the studied areas, after checking the normality of the data and the independence of samples. Spearman rank 


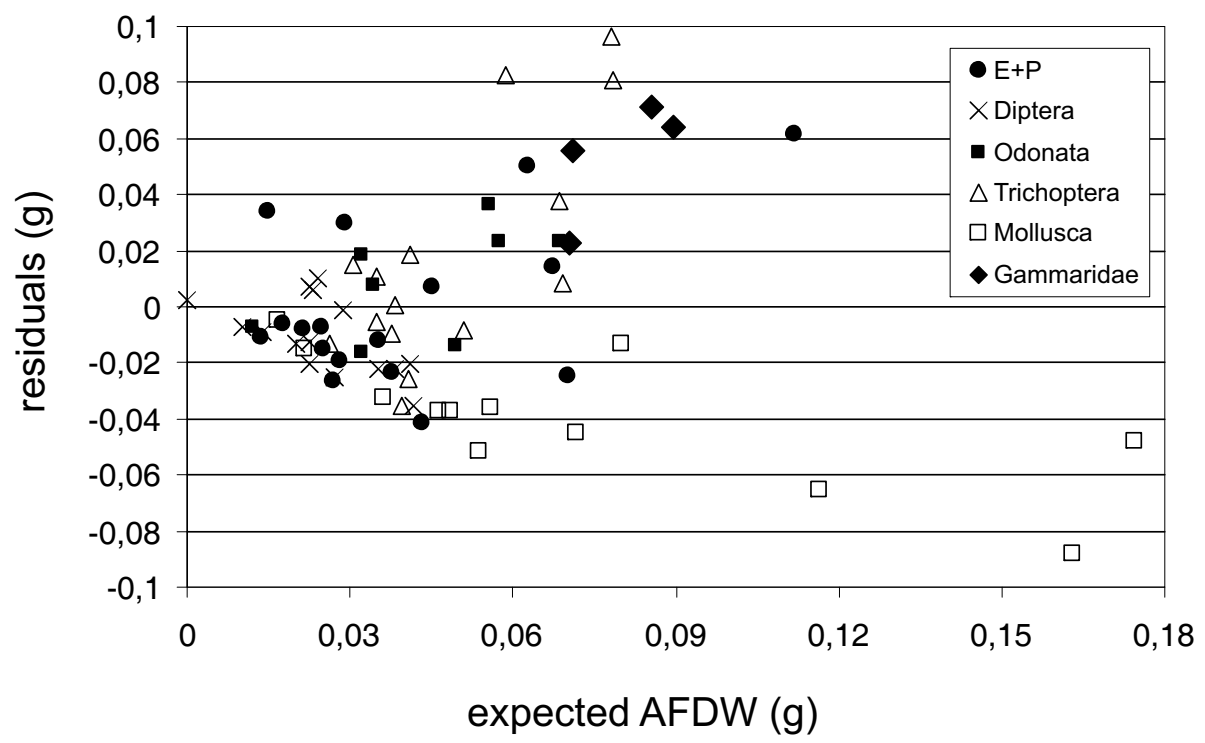

Figure 2. Regression analysis between the dry weight and ash-free dry weight: the residual versus expected values of AFDW. E+P: Ephemeroptera and Plecoptera. Análisis de regresión entre el peso seco y el peso seco libre de cenizas: representación de los residuales respecto a los valores esperados de PSLC. E+P = efemerópteros y plecópteros.

correlations were performed to analyse the relationships between the macroinvertebrate abundance and biomass (FW, DW and AFDW) and the trout population demographic conditions of density and biomass (total and by age classes), average weight and population age structure. All of the analyses were performed using the Statgraphics Plus software (Manugistics, Inc. 1997. Rockville, Maryland. U.S.A).

(X 1000)

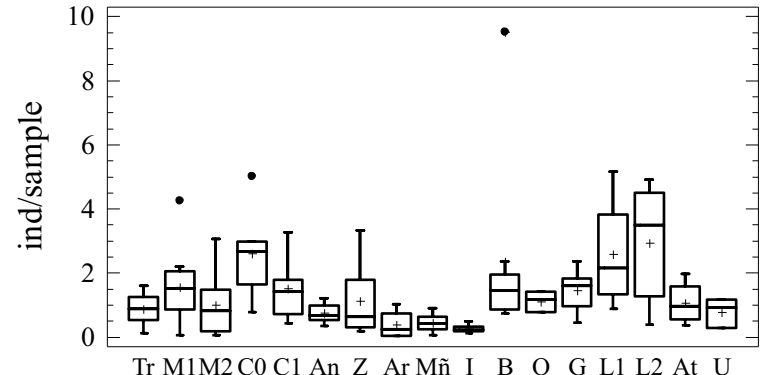

\section{RESULTS}

\section{Biomass estimates}

The average biomasses, as fresh weight (FW), dry weight (DW) and ash-free dry weight (AFDW), of 80 macroinvertebrate families present in the sampled rivers of Biscay - out of the 127 families located on the Iberian Peninsula reported by

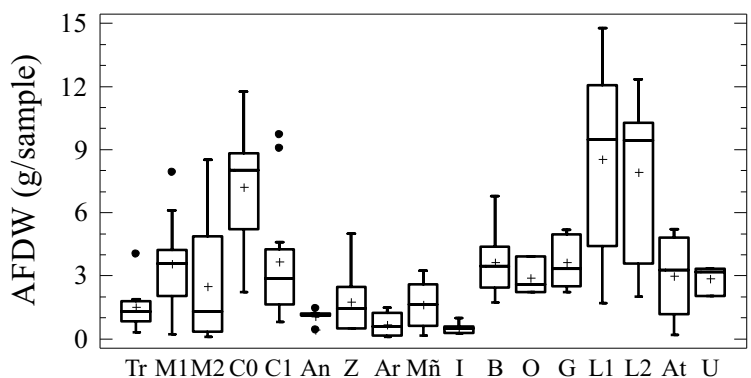

Sampling sites

Figure 3. Macroinvertebrate abundance (left panel) and biomass as the AFDW (right panel) for each sampling site from 1997 to 2006. The sampling site codes are as in Figure 1. The box plots show the means (cross), medians (horizontal line inside the box), I and IV percentiles (edges of the box) and outliers (separated points). Distribución de los valores de abundancia (izquierda) y biomasa en PSLC (derecha) de macroinvertebrados para cada estación desde 1997 a 2006. Códigos de las estaciones de muestreo en la Figura 1. Los diagramas de cajas muestran las medias (cruz), las medianas (línea horizontal dentro de la caja), los percentiles I y IV (extremos de la caja) y los "outliers" (puntos aislados). 
Alba-Tercedor \& Pujante, (2000); Jáimez-Cuellar et al., (2002) - have been deposited in the Limnetica web (Appendix 1; www.limnetica.net/internet/ index.html). We collected enough fresh material in this work to estimate the biomass of 32 cases. Of the 48 remaining families, 28 had a frequency lower than $9 \%$ and a relative abundance below $3 \%$, and the remaining 20 families had greater frequencies, but their relative abundance did not exceed $10 \%$. Only one size class was established in most of the families. Two size classes were established for Glossiphoniidae, Heptageniidae, Limnephilidae, Sericostomatidae, Chironomidae and Oligochaeta, and three size classes were set for Gomphidae (Appendix 1).

For the combined data of all of the families, there was a significant relationship between the
AFDW and the DW that fit a logarithmic model: $\mathrm{AFDW}=0.16+0.08 * \ln (\mathrm{DW})\left(R^{2}=0.457\right.$, $P<0.001, N=84)$.

Molluscs, however, did not fit this model. Molluscs had a lower AFDW than expected, because they were weighed with their shells (Fig. 2). In contrast, Gammaridae and some Trichoptera had higher values of AFDW due to their higher organic matter content and, as a related factor because they were weighed without their cases.

\section{Applied study: brown trout populations}

Significant differences among the sampling sites were observed in the densities of the macroinvertebrates $(F=2.91 ; \mathrm{df}=16,100 ; P<0.001)$ and total biomass, expressed as the AFDW $(F=6.52$;

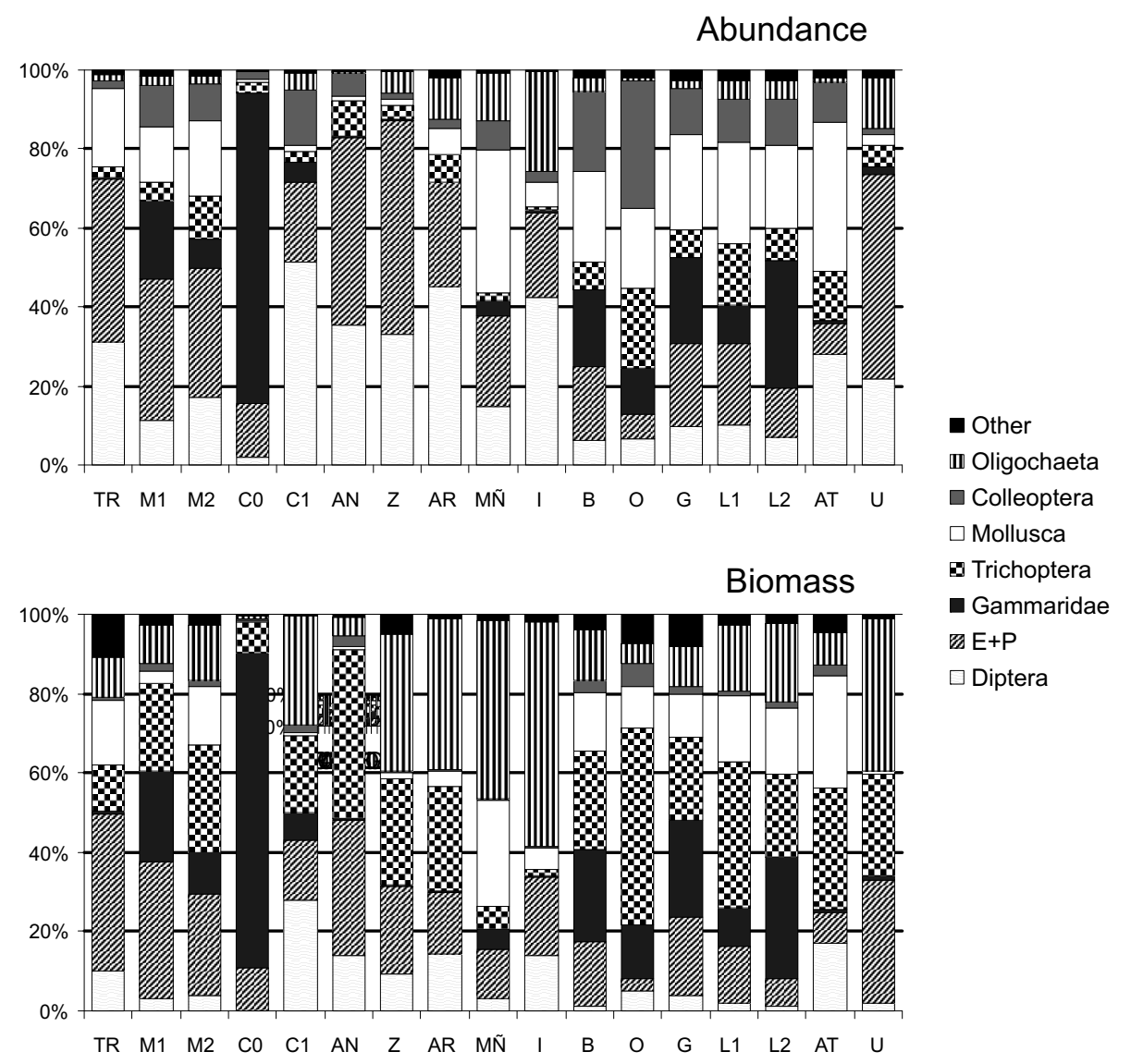

Figure 4. Average faunal composition at each sampling site from 1997 to 2006, in terms of the abundance (upper panel) and biomass (lower panel). E + P: Ephemeroptera and Plecoptera. Composición faunística media de cada estación entre los años 1997 a 2006, en términos de abundancia (superior) y biomasa (inferior). $E+P=$ efemerópteros y plecópteros. 
df $=16,100 ; P<0.001)($ Fig. 3$)$. The highest values of abundance and biomass were found in Lea (L1 and L2) and Cadagua (C0), and the lowest values were found in Ibaizabal (I) and Arratia (Ar), ranging from $260 \pm 142$ (standard deviation, SD) to $2933 \pm 1670 \mathrm{ind} / \mathrm{sample}$ and from $0.50 \pm 0.30$ to $8.54 \pm 4.62 \mathrm{~g} / \mathrm{sample}$, respectively.

The faunal composition was also analysed, and different macroinvertebrate communities were observed (Fig. 4). Gammarids, true flies, mayflies and stoneflies, caddisflies and molluscs were the most important faunal groups in terms of abundance. In some cases, a single family was clearly dominant, such as the gammarids upstream in the Cadagua River (C0). In others, half of the sample was made up of one or two taxa, such as diptera in the other station of Cadagua (C1), or mayflies and stoneflies in Zeberio (Z), Urkiola (U) and Arnauri (An). Molluscs were important in Artibai (At) and Mañaria (Mñ).

Gammarids also dominated the biomass in the Cadagua River (up to $80 \%$ in C0) and, to a lesser extent, downstream in Lea (L2), while mayflies and stoneflies were dominant in Agüera (Tr) and in the upper stretch of the Mayor river (M1). True flies, molluscs and beetles contributed with very low AFDW. In contrast, Trichoptera showed greater biomass being more important even in rivers where they did not show high relative abundance, as in the Oka River $(\mathrm{O})$, with a mean value up to $50 \%$, Arnauri (An), upper stretch of Lea River (L1) and Mayor River (M2). Although the relative abundance of oligochaetes was low in all of the cases, this group had a high relative biomass in some of the stations, such as in Ibaizabal (up to $57 \%$ ), Mañaria or Arratia and Urkiola.

The macroinvertebrates were assigned to six functional feeding groups: predators, scrapers, shredders, collector-gatherers, collector-filterers and collector-gatherer-scrapers (Appendix 1). As for the faunistic composition, differences were also observed among the samples, but more detailed analyses are not included here.

Significant differences among the studied brown trout populations were observed in both the density $(F=19.68 ; \mathrm{df}=16,96 ; P<0.001)$ and biomass $(F=3.41$; df $=16,95 ; P<0.001)$ per $100 \mathrm{~m}^{2}$ (Fig. 5). The highest values were ob- served in the upper stretch of Cadagua (C0: 14.1 \pm 3.5 trout $/ 100 \mathrm{~m}^{2}$ and $\left.979 \pm 243 \mathrm{~g} / 100 \mathrm{~m}^{2}\right)$. The trout density was also high in the Mañaria and Golako (G) rivers, but in those cases, the high density did not correspond to a high biomass; the Mañaria, indeed, had the lowest average biomass of all of the studied sites $\left(50 \pm 39 \mathrm{~g} / 100 \mathrm{~m}^{2}\right)$.

Several significant Spearman rank correlations between the macroinvertebrate and trout demographic parameters were found (66 significant correlations out of 1056 analysed pairs). The trout population size, based on both density and biomass, was positively correlated to the macroinvertebrate total sample abundance and biomass and also to the abundance and biomass of gammarids and shredders. The trout biomass
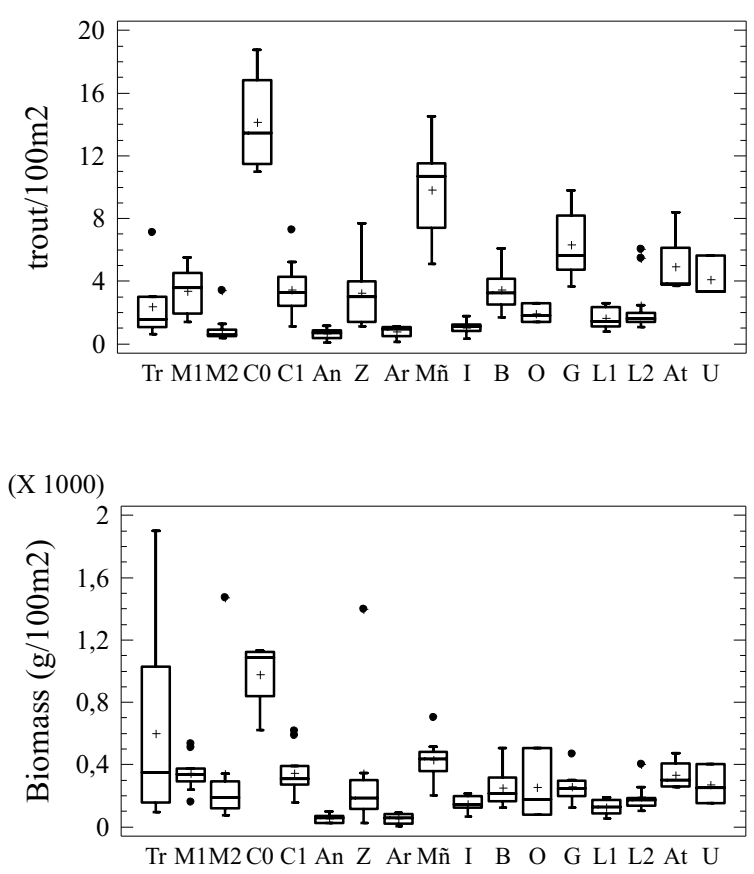

Sampling sites

Figure 5. Distribution of the brown trout density (upper panel) and biomass (lower panel) for each sampling site from 1997 to 2006. The box plots show the means (cross), medians (horizontal line inside the box), I and IV percentiles (edges of the box) and outliers (separated points). Distribución de los valores de densidad (superior) y biomasa (inferior) de truchas para cada estación desde 1997 a 2006. Los diagramas de cajas muestran las medias (cruz), las medianas (linea horizontal dentro de la caja), los percentiles I y IV (extremos de la caja) y los “outliers" (puntos aislados). 
was negatively correlated to the abundance of collector-gatherers. The $1+$ trout age class was positively related to the macroinvertebrate abundance and biomass, and the $2+$ class was positively correlated with the gammarid and shredder abundance and biomass. Other demographic parameters (the remaining age classes, age structure of the population and trout average weight) did not show any significant relationships to the macroinvertebrate parameters.

\section{DISCUSSION}

Indirect estimates of macroinvertebrate biomass involving length and weight measures have been used in numerous studies (e.g. Hutchens et al., 1998; Miserendino, 2001; Gonzalez et al., 2002; Stoffels et al., 2003). The same regressions have even been used to estimate the biomass of macroinvertebrates from different geographic areas (Johnston \& Cunjak, 1999). Regression models rely on the measurement of a great number of individuals and the use of a different equation for each taxon (Hutchens et al., 1998). In addition, these methods require fresh material because fixation alters the length, volume, and biomass of macroinvertebrates. Johnston \& Cunjak (1999) suggested the use of length-biomass relationships with fresh organisms and the need to establish a correction factor when preserved material was employed in the assessment of biomass. The use of conversion factors to compensate for the changes caused by fixation on the biomass of organisms has also been proposed (Meyer, 1989). Frozen material has been used to develop lengthweight relationships (Meyer, 1989, Wenzel et al., 1990; Burgherren \& Meyer, 1997), but weights are also altered by freezing.

Bioassessments of freshwater systems routinely involve the collection of biosurvey data focused on macroinvertebrates, and many of those samples have to be preserved because they are best processed in a laboratory under controlled conditions (Barbour et al., 1999). Moreover, the immediate sorting and analysis of samples is not always possible due to the great number of samples collected during monitoring studies. The av- erage biomasses of different taxa (Appendix 1) should allow researchers to estimate biomass from invertebrate densities.

In the present study, Trichoptera showed a great relative dominance based on their ash-free dry weight (AFDW) but not on their abundance, and large oligochaetes had also high values of AFDW, although they were usually found in low abundance. In contrast, true flies, mayflies and stoneflies were relatively important in several of the sampling sites in terms of abundance but not of biomass. Finally, groups with a high degree of sclerotisation, such as beetles and molluscs, contributed little to the AFDW biomass of the sample.

The dry weight (DW) and AFDW were significantly correlated. In this study, the use of the AFDW was considered to be more useful from a biological point of view because it represents the real organic biomass value that is transferred along the food chain. The use of the AFDW is also recommended because it solves the problem of samples in which shells can account for high values of DW, such as molluscs (Anonymous, 1986). With the AFDW, the overestimation of the energy contribution of those taxa could be avoided. The absolute content of nutrients in the macroinvertebrates was important for the prey selection by the trout (Montañés \& Lobón Cerviá, 1986; Ruginis, 2008). Elmidae beetles were rejected by the $0+$ trout, perhaps due to their low energy content because they were intensely sclerified, whereas there was a positive selection of Rhyacophilidae, which had a higher energy content and their consumption also implied a low predation risk (Oscoz et al., 2005).

As expected, the brown trout population size (based on both density and biomass) was positively correlated to both the macroinvertebrate abundance and biomass because macroinvertebrates were the main component of the trout diet (López-Álvarez, 1984; Oscoz et al., 2000; 2005; Almodovar et al., 2006, Ruginis, 2008). The high values of all of the macroinvertebrate parameters in the tested rivers imply high productivity, good freshwater habitat and adequate amounts of food for the trout. In this work, a positive selection of gammarids and shredders by the trout was observed. Trout select their prey according 
to different factors, such as availability, accessibility, energy, predation risk and kind of habitat (Montañés \& Lobón-Cerviá, 1986; Oscoz et al., 2005; Ruginis, 2008). Gammarids and shredders dominated the macroinvertebrate communities in the river stretches where the trout densities were also high. Trout are visual predators that select active benthic macroinvertebrates, such as true flies, mayflies and caddisflies, with a high rate of drift (Oscoz et al., 2005; Ruginis, 2008). In contrast, small prey, such as chironomids, or prey that are camouflaged and hidden in the soil or vegetation (such as oligochaetes, molluscs, crane-flies, horse-flies, bugs and dragonflies) are more difficult to detect, and a lower consumption of these groups was expected (LópezÁlvarez, 1984; Oscoz et al., 2005). Gammarids are easily captured by trout (Ruginis, 2008), and in some rivers, they were the most important food source, representing up to $70 \%$ of the total volume of the trout stomach contents (LópezÁlvarez, 1984). Moreover, in the DW-AFDW biomass model obtained in this work, Gammaridae showed more elevated values of AFDW than expected, with a high content of organic matter.

The individual trout average weight was not correlated with either the macroinvertebrate abundance or biomass, probably because the increase of macroinvertebrates is equivalent to a greater availability of food, implying a positive increment of the carrying capacity of the system. In density-dependant populations, this relationship would let the rivers contain a higher number of trout but not necessarily larger trout individuals.

The relationship among the brown trout population density and biomass and the macroinvertebrates (density and biomass) was significant only for the $1+$ and $2+$ trout classes. Besides food availability, there are other factors explaining trout population demographics, such as the general riverine condition, abundance of predators, density dependence, and the availability of refuges and spawning areas (Antón, 2006; Antón et al., 2010). Finally, brown trout are fished extensively in this region, and the harvest also influences the densities and size structure of the populations. Some of the river stretches with good habitat quality had fewer $0+$ trout than ex- pected (the rivers Agüera [Tr] and Mayor [M2]). For several years, those streams were "intensive" fishing preserves and many non-native trout of catchable size were annually introduced. Those populations were the most unstructured of all of the studied populations.

The macroinvertebrate community biomass factors reported here complement the results of other environmental studies. The application of the macroinvertebrate average biomass values obtained in this work to previous samples from the rivers of Biscay provided additional information that was not provided by abundance measurements. The average biomasses reported here could be a useful tool for other limnologists.

\section{REFERENCES}

ALBA-TERCEDOR, J. \& A. M. PUJANTE. 2000. Running-water biomonitoring in Spain: opportunities for a predictive approach. In: Assessing the biological quality of freshwaters: RIVPACS and other techniques in Freshwater Biological Association. J. F. Wright et al. (eds.): 207-216. Ambleside, UK.

ALLAN, J. D. 1995. Stream Ecology. Structure and function of running waters. Kluwer Academic Publishers. Dordrecht, Netherlands. 388 pp.

ALMODOVAR, A. NICOLA, G. G. \& B. ELVIRA. 2006. Spatial variation in brown trout production: the role of environmental factors. Transactions of the American Fisheries Society. 135: 1348-1360.

ANONYMOUS. 1986. Fifth report of the Benthos Ecology Working Group. Ostende. Int. Counc. Explor. Sea (CM Pap. Rep.), CM 1986/L: 27-33 pp.

ANTÓN, A. 2006. Peces fluviales de Bizkaia: Distribución, Demografía y nicho ecológico con aplicaciones de gestión. Tesis Doctoral. Universidad del País Vasco. 473 pp.

ANTÓN, A., A. ELOSEGI, L. GARCÍA-ARBERAS, J. R. DÍEZ \& A. RALLO. 2010. Restoration of dead wood in Basque stream channels: effects on brown trout population. Ecology of freshwater fish. doi: 10.1111/j.1600-0633.2010.00482.x.

BASAGUREN, A., A. ELOSEGUI \& J. POZO. 1996. Changes in the trophic structure of benthic macroinvertebrate communities associated with food availability and stream flow variations. Archiv für.Hydrobiologie, 81: 79-91. 
BARBOUR, M. T., J. GERRITSEN, B. D. SNYDER \&J. B. STRIBLING. 1999. Rapid bioassessment protocols for use in streams and wadeable rivers: periphyton, benthic macroinvertebrates and fish. $2^{\text {nd }}$ edition. EPA 841-B-99-002. U.S. Environmental Protection Agency; Office of Water; Washington D.C.

BIS, B., A. ZDANOWICZ \& M. ZALEWSKI. 2000. Effects of catchment properties on hydrochemistry, habitat complexity and invertebrate community structure in a lowland river. Hydrobiologia, 422/423: 369-387.

BROWER, J. E. \& J. H. ZAR. 1979. Field and laboratory methods for General Ecology. Brown Company Publishers. USA. 194 pp.

BURGHERR, P. \& E. I. MEYER. 1997. Regression analysis of linear body dimensions vs. dry mass in stream macroinvertebrates. Archiv für. Hydrobiologie, 139: 101-112.

CRISP, D. J. 1984. Energy flow measurements. In: Methods for the study of marine benthos. N. A. Holme \& A. D. McIntyre (eds.): 284-372. Blackwell Scientific Publications. Oxford.

DERMOTT, R. M. \& C. G. PATERSON. 1974. Determining dry weight and percentage dry matter of chironomid larvae. Canadian Journal Zoology, 52: 1243-1250.

GONZÁLEZ, J. M., A. BASAGUREN \& J. POZO. 2002. Size-mass relationships of stream invertebrates in a northern Spain stream. Hydrobiologia, 489: 131-137.

HAUER, F. R. \& A. C. BENKE. 1987. Influence of temperature and river hydrograph on black fly growth rates in a subtropical blackwater river. Journal of the North American Benthological Society, 6: 251-261.

HAUER, F. R. \& V. H. RESH. 1996. Benthic Macroinvertebrates. In Methods in stream ecology. R. Hauer \& G. Lamberti (eds.): 339-365. Academic Press. San Diego (California).

HELLAWELL, J. M. 1986. Biological indicators of freshwater pollution and environmental management. Elsevier. Essex, UK. 545 pp.

HUTCHENS, J. J., K. CHUNG \& J. B. WALLACE. 1998. Temporal variability of stream macroinvertebrate abundance and biomass following pesticide disturbance. Journal of the North American Benthological Society, 17: 518-534.

JÁIMEZ-CUELLAR, P. y 18 autores. 2002. Protocolo GUADALMED (PRECE). Limnetica, 21: 187204.
JENSEY, J. L., P. W. M. CORBETT \& L. W. LAKE. 2000. Statistics for petroleum engineers and geoscientist. Elsvier. Amsterdan. 338 pp.

JOHNSTON, T. A. \& R. A. CUNJAK. 1999. Dry mass-length relationships for benthic insects: a review with new data from Catamaran Brook, New Brunswick, Canada. Freshwater Biology, 41: 653674.

KWAK, T. J. 1992. Modular microcomputer software to estimate fish population parameters, production rates and associated variance. Ecology of Freshwater Fish, 1: 73-75

LEUVEN, R. S. E. W., T. C. M. BROCK \& H. A. M. VAN DRUTEN. 1985. Effects of preservation on dry- and ash- free dry weight biomass of some common aquatic macro-invertebrates. Hydrobiologia, 127: 151-159.

LOBÓN-CERVIÁ, J. 1991. Dinámica de peces en ríos. Pesca eléctrica y métodos de capturas sucesivas en la estima de abundancias. Museo Nacional de Ciencias Naturales (CSIC), Monografías No. 3, Madrid, $156 \mathrm{pp}$.

LÓPEZ-ÁLVAREZ, J. V. 1984. Observaciones sobre la alimentación natural de la trucha comun (Salmo trutta fario L.) en algunos ríos de la cuenca del Duero. Limnetica, 1: 247-255.

MERRIT, R. W. \& K. W. CUMMINS. 1978. An introduction to the aquatic insects of North America. Kendall/Hunt. Dubuque, Iowa. 441 pp.

MEYER, E. 1989. The relationship between body length parameters and dry mass in running water invertebrates. Archiv für Hydrobiologie, 117: 191203.

MISERENDINO, M. L. 2001. Length-mass relationships for macroinvertebrates in freshwater environments of Patagonia (Argentina). Ecología Austral, 1: 3-8.

MONTAÑÉS, C. \& J. LOBÓN-CERVIÁ. 1986. Feeding ecology of a population of brown trout (Salmo trutta L.) in an aquifer stream of old Castile, Spain. Ekologia Polska, 34: 203-213.

MONZÓN, A., C. CASADO, C. MONTES \& D. GARCÍA DE JALÓN. 1991. Organización funcional de las comunidades de macroinvertebrados acuáticos de un sistema fluvial de montaña (Sistema Central, río Manzanares, España). Limnetica, 7: 97-112.

ORMEROD, S. J., M. E. JONES, M. C. JONES \& D. R. PHILLIPS. 2004. The effects of riparian forestry on invertebrate drift and brown trout in 
upland streams of contrasting acidity. Hydrology and Earth System Sciences, 8: 578-588.

OSCOZ, J., M. C. ESCALA \& F. CAMPOS. 2000. La alimentación de la trucha común (Salmo trutta L., 1758) en un río de Navarra (N. España). Limnetica, 18: 29-35.

OSCOZ, J., P. M. LEUNDA, F. CAMPOS, M. C. ESCALA \& R. MIRANDA. 2005. Diet of $0^{+}$brown trout (Salmo trutta L., 1758) from the river Erro (Navarra, north of Spain). Limnetica, 24 (3-4): 319-326.

PUIG, M. A. 1999. Els macroinvertebrats dels rius Catalans. Generalitat de Catalunya. Departament de Medi Ambient. España. 251 pp.

RALLO, A. 1992. Caracterización hidrobiológica de la red fluvial de Álava y Gipuzkoa. Gobierno Vasco, Dpto. Medio Ambiente, Vitoria. 512 pp.

RALLO, A., A. ANTON \& L. GARCÍA-ARBERAS. 2007. Estudio de peces de los ríos de Bizkaia. Campañas 2002-2006. Universidad del País Vasco. 223 pp. (Informe inédito para la Diputación Foral de Bizkaia, Dpto. Agricultura, Espacios naturales).

RALLO, A., L. GARCÍA-ARBERAS \& A. ANTÓN. 2001. Estudio de peces de los ríos de Bizkaia. Campañas 1997 a 2001. Universidad del País Vasco. 165 pp. (Informe inédito para la Diputación Foral de Bizkaia, Dpto. Agricultura, Espacios naturales).

RICO, E., A. RALLO, M. A. SEVILLANO \& M. L. ARRETXE. 1992. Comparison of several biological indices based on river macroinvertebrate ben- thic community for assessment of running water quality. International Journal of Limnology, 28: 147-156.

RODRIGUES-CAPÍTULO, A., I. MUÑOZ, N. BONADA, A. GAUDES \& S. TOMANOVA. 2009. La biota de los ríos: los invertebrados. En: Conceptos y técnicas en ecología fluvial. A. Elosegui \& S. Sabater (eds.): 253-270. Fundación BBVA. España.

RUGINIS, T. 2008. Diet and prey selectivity by age-0 brown trout (Salmo trutta L.) in different lowland streams of Lithuania. Acta Zoologia Lituanica, 18 (2): 139-146.

SOKAL, R. R. \& F. J. ROHLF. 1995. Biometry: the principles and practice of statistics in biological research. W. H. Freeman and Company. New York. 887 pp.

STOFFELS, R. J., S. KARBE \& R. A. PATERSON. 2003. Length-mass models for some common New Zealand littoral-benthic macroinvertebrates, with a note on within-taxon variability in parameter values among published models. New Zealand Journal of Marine and Freshwater Research, 37: 449460.

TACHET, H., P. RICHOUX, M. BOURNAUD \& P. USSEGLIO-POLATERA. 2000. Invertébrés d'eau douce, systématique, biologie, écologie. CNRS Editions. París. 588 pp.

WENZEL, F., E. MEYER \& J. SCHWOERBEL. 1990. Morphometry and biomass determination of dominant mayfly larvae (Ephemeroptera) in running waters. Archiv für Hydrobiologie, 118 (1): 31-46. 